\title{
Barley Grain Yield and Protein Content Response to Deficit Irrigation and Sowing Dates in Semi-Arid Region
}

\author{
Amir Tabarzad $^{1}$, Ali Asghar Ghaemi ${ }^{2} \&$ Shahrokh Zand-Parsa ${ }^{2}$ \\ ${ }^{1} \mathrm{PhD}$ student in Water Engineering, Water Engineering Department, College of Agriculture, Shiraz University, \\ Shiraz, Iran \\ ${ }^{2}$ Associate Professor in Water Engineering, Water Engineering Department, College of Agriculture, Shiraz \\ University, Shiraz, Iran \\ Correspondence: Ali Asghar Ghaemi, Water Engineering Department, College of Agiculture. Shiraz University, \\ Shiraz, Iran. Tel: 9871-3226-6226. E-mail: ghaemiali@yahoo.com/ghaemi@shirazu.ac.ir
}

Received: May 16, 2016

Accepted: May 27, 2016

Online Published: July 27, 2016

doi:10.5539/mas.v10n10p193

URL: http://dx.doi.org/10.5539/mas.v10n10p193

\begin{abstract}
The present study was conducted to investigate the relational effects of various sowing dates and deficit irrigation on grain yield, protein and yield components of barley, in a semi-arid region (southern part of Iran) during growing seasons 2011-2012 and 2012-2013. A Split plot layout within a randomized complete block design with three replications was used. Main plots were selected as Irrigation treatments with varying water irrigation levels consisting of: (1) full irrigation, FI, (2) 0.75 FI, (3) 0.5 FI and (4) Dry land (rain-fed) during both growing seasons. Sub plots were the sowing dates consisted of: (1) $23^{\text {th }}$ October (T1), (2) $6^{\text {th }}$ and (3) $22^{\text {th }}$ November (T2 and T3) and (4) $6^{\text {th }}$ December (T4). The interaction of different irrigation levels and sowing dates had a significant impact $(\mathrm{p}<0.05)$ on grain yield, grain and straw protein, 1000-grain weight, plant height, biomass, water use efficiency (WUE), and crop evapotranspiration. Results revealed that the largest amount of protein was obtained in the latest sowing date (T4) at dry land treatment in two consecutive years. Full irrigation treatment showed the largest rate of dry matter accumulation (14.72 and $15.25 \mathrm{Mg} \cdot \mathrm{h}^{-1}$ for the first and second years, respectively), while the smallest rate was seen in the rain fed treatment (4.22 and $7.43 \mathrm{Mg} \cdot \mathrm{h}^{-1}$ for the first and second years, respectively). The largest yield was obtained with the $23^{\text {th }}$ October (T1) sowing date in full irrigation treatments (FI). The largest water use efficiency was achieved with $0.5 \mathrm{FI}$ and the earliest sowing date (T1).
\end{abstract}

Keywords: Barley, deficit irrigation, sowing date, water use efficiency, yield components

\section{Introduction}

Barley (Hordeum, V. L.) is the world's fourth most important crop after rice, wheat and maize in terms of cultivated area. Recent years of below normal precipitation has resulted in Iran having a serious water crisis and shortage of irrigation water in the most part of country. One of the major causes for the current water crisis is mismanagement and inefficiency in the agriculture sector. Consequently the strategy of deficit irrigation needs to be investigated. Deficit irrigation is an optimizing strategy under which crops are deliberately allowed to sustain some degree of water deficit and yield reduction (English \& Raja, 1996; Ghaemi \& Tabarzad, 2014). Plants are exposed to certain levels of water stress during either a particular growth period or throughout the whole growth season. Such deficient irrigation programs significantly reduce the water applied below the crop's water requirement and evapotranspiration (Kirda \& Kanber, 1999; Tabarzad \& Ghaemi, 2015). The main approach in deficit irrigation practice is to maximize net benefits by eliminating those irrigations with the least impact on crop yield. Water use efficiency, WUE, is defined as the ratio of grain yield to total growing season evapotranspiration (Kang \& Zhang, 2004; Kirda \& Kanber, 1999). In the areas where water supplies are limited and unit water costs are expensive, the best irrigation practice is not necessarily that which gives the highest yield (English \& Raja, 1996; Tabarzad \& Ghaemi, 2015). Shabani et al. (2010) indicated that deficit irrigation had negative significant effect on yield and yield quality of rapeseed such as weight of 1000-grain weight, seed oil and seed protein content. Water productivity is an important parameter for the evaluation of deficit irrigation strategies. Geerts and Raes (2009) reported that in arid and semi-arid areas, deficit irrigation enhances water productivity in comparison with rain-fed and full irrigation cultivation. Sowing date controls the crop yield. The 
differences in yield components of early and late sown crops may be due to favorable temperatures at different growth stages, which may increase photosynthetic, rate in early sown crops over late planting (Rashid \& Ullahkhan, 2010). On the other hand, the sowing date per field depends on suitability of the soil for cultivation, date of harvest of the preceding crop, soil temperature and farmer's priorities for sowing. Actual and expected rainfall may influence the timing of sowing (Supit \& Wagner, 1999). Many researchers indicated that early planting increased the yield attributes and yield production of different crops than late planting in different climatic condition (Ali et al., 2009; Amjadian et al., 2013; Hassan \& Nhemachena, 2008; Noworolnik, 2012; Rashid \& Ullahkhan, 2010; Sarker et al., 2012). Ozer (2003) found that up to 71\% more grain yield is achievable by earlier sowing than late sowing of barley. Yield improvement with early seeding varied from $47 \%$ to $20 \%$ in central and southern Alberta, respectively (Mckenzie et al., 2005). Effects of late seeding on protein content have varied from no effects (Juskiw \& Helm, 2003), minor increases or relatively large increases (Mckenzie et al., 2005). These differences in yield and protein content, as affected by seeding date, may be related to differences in the length of the intervals between seeding dates among the different experiments (Mckenzie et al., 2005). However the shorter growing season, additional costs associated with irrigation and the lower yield potential of barley may reduce grower profits. There has been a trend towards earlier sowing to take advantage of winter rainfall, which however comes at the risk of greater frost damage (Acuña \& Wade, 2013).

The objectives of this study are: I) to investigate the relative response of barley under different sowing dates and determine the optimal sowing date in semi-arid region; II) to determine the effects of deficit irrigation on yield and yield components; III) to investigate the relational effects of various sowing dates and deficit irrigation on barley grain yield and protein content.

\section{Methods and Materials}

\subsection{Field Experiment}

This experiment was conducted at the Experimental Research Station at the College of Agricultural, Shiraz University, a semi-arid region in the southern part of Iran during two different growing seasons (2011-2012 and 2012-2013). Physical properties of the soil at different depth are shown in Table 1. Average electrical conductivity (EC) of irrigation water was $0.6 \mathrm{ds} \mathrm{m}^{-1}$. Experimental design was a split plot (Split block) design with 3 replicates arrangement in randomized complete block design with irrigation treatments as the main plots and the sowing dates as the subplots. The dimension of each plot was $3 \times 4 \mathrm{~m}^{2}$ and distance between two adjacent plots was $1.0 \mathrm{~m}$ to prevent water invasion from one plot to another. Three levels of irrigation treatments consisted of: water requirement (full irrigation, FI), 75 and 50 percent of full irrigation ( $0.75 \mathrm{FI}$ and $0.5 \mathrm{FI})$ and Dry land (rain-fed) as the main plot were applied. Four different sowing dates consisted of: $23^{\text {th }}$ October (T1), $6^{\text {th }}$ and $22^{\text {th }}$ November (T2 and T3) and $6^{\text {th }}$ December (T4) as the subplot were considered in two growing seasons. Bahman cultivar of barley (a local cultivar) was used in this experiment. Seeds were sowed in 13 rows with spacing between rows of $0.2 \mathrm{~m}$ with seed planting rate of $200 \mathrm{~kg} \mathrm{ha}^{-1}$. Each plot was irrigated with about $110 \mathrm{~mm}$ of water to ensure better seedling establishment at the first day of cultivation. Soil water content was measured by neutron scattering method at different depths of $0.3,0.6,0.9,1.2 \mathrm{~m}$ of soil surface before each irrigation event The Irrigation interval was 7 to 10 days (Figure 1). Figure 2 shows minimum, maximum and average temperature of the cultivated area for two years of experiment. Precipitation was recorded at a standard weather station located about $50 \mathrm{~m}$ far from the plots. Soil water content in the root zone was used to determine the amount of net irrigation water as calculated by Equation 1:

$$
d_{n}=\sum_{i=1}^{n}\left(\theta_{f c i}-\theta_{i}\right) \times \Delta z_{i}
$$

Where $d_{n}$ is the net irrigation water depth $(\mathrm{m}), \theta_{f c i}$ and $\theta_{\mathrm{i}}\left(\mathrm{m}^{3} \cdot \mathrm{m}^{-3}\right)$ are the volumetric soil water content at the field capacity and in layer $i$ before irrigation, respectively, $\Delta z$ is the soil layer thickness $(\mathrm{m})$ and $n$ is the number of soil depth layers. 
Table 1. Soil physical characteristics of the experimental site

\begin{tabular}{lllll}
\hline \multirow{2}{*}{ Physical properties } & \multicolumn{5}{l}{ Soil depth $(\mathrm{cm})$} \\
\cline { 2 - 5 } & $0-30$ & $30-60$ & $60-90$ & $90-120$ \\
\hline $\mathrm{FC}\left(\mathrm{cm}^{3} \mathrm{~cm}^{-3}\right)$ & 0.32 & 0.33 & 0.33 & 0.33 \\
$\mathrm{PWP}\left(\mathrm{cm}^{3} \mathrm{~cm}^{-3}\right)$ & 0.16 & 0.18 & 0.19 & 0.19 \\
$\rho b\left(\mathrm{~g} \mathrm{~cm}^{-3}\right)$ & 1.43 & 1.43 & 1.43 & 1.43 \\
Clay $(\%)$ & 31 & 38 & 35 & 30 \\
Silt $(\%)$ & 57 & 52 & 49 & 53 \\
Sand $(\%)$ & 12 & 10 & 16 & 17 \\
\hline Soil texture & \multicolumn{5}{l}{} \\
\hline
\end{tabular}

Note. FC: Field Capacity, PWP: Permanent Wilting Point, $\rho b$ : Bulk density.
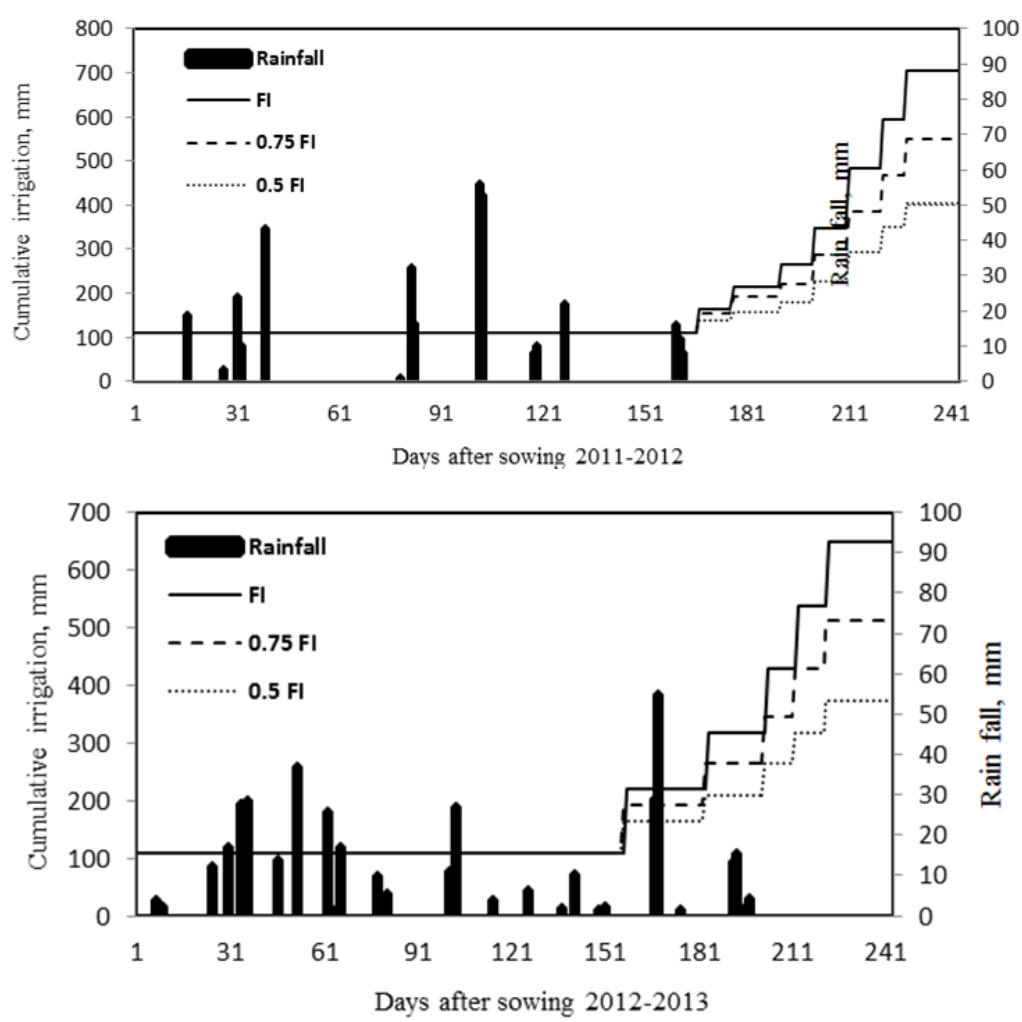

Figure 1. Cumulative applied irrigation (FI, 0.75 FI and 0.5 FI) water and rainfall in 2011-2012 and 2012-2013 for the first sowing date ( 23 October)

\section{1-2012}

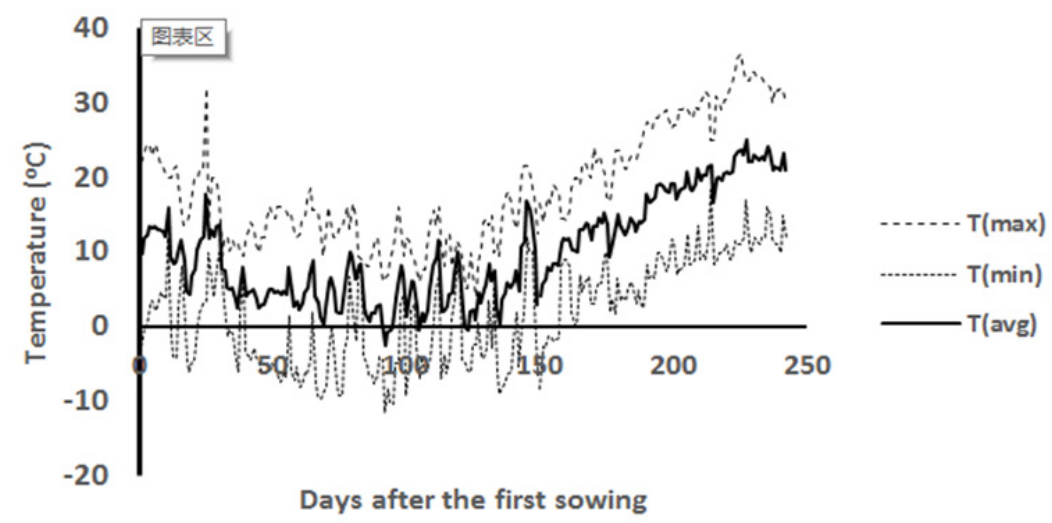


2012-2013

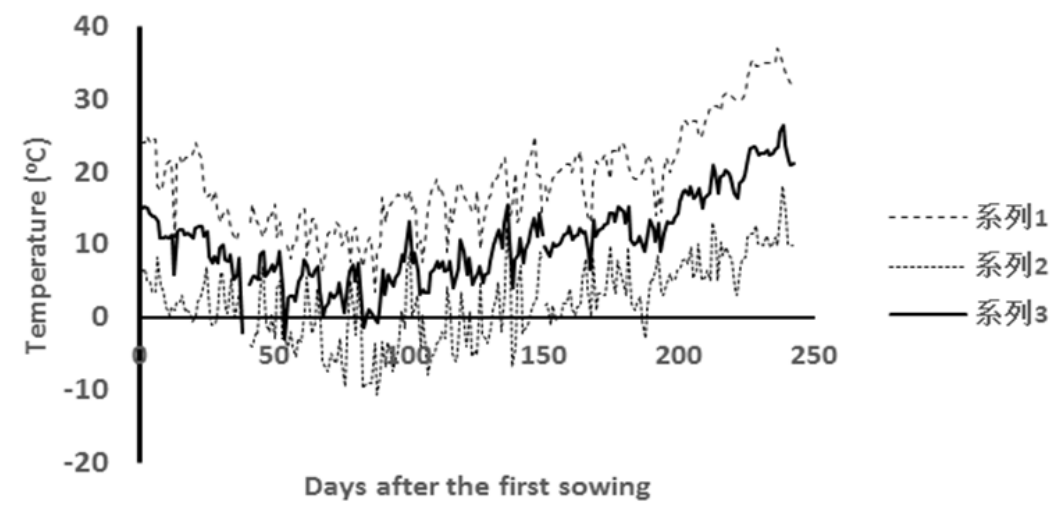

Figure 2. Minimum, maximum, and average daily temperature in two consecutive years (2011-2012 and 2012-2013)

Depth of root was estimated by Equation 2 (Raes et al., 2010):

$$
z=z_{0}+\left(z_{x}-z_{0}\right) \sqrt[n]{\frac{\left(t-\frac{t_{0}}{2}\right)}{\left(t_{x}-\frac{t_{0}}{2}\right)}}
$$

where $Z$ : effective rooting depth at time $t(m) ; Z_{0}$ : starting depth of the root zone expansion curve $(m) ; Z_{x}$ : maximum effective rooting depth $(\mathrm{m}) ; \mathrm{t}_{\mathrm{o}}$ : time to reach $90 \%$ crop emergence (days or growing degree days); $\mathrm{t}_{\mathrm{x}}$ : time after planting when $Z_{x}$ is reached (days or growing degree days); t: time after planting (days or growing degree days); $\mathrm{n}$ shape factor (1.5).

The crop evapotranspiration for the irrigation intervals was estimated by the water balance method using the Equation 3:

$$
E T=I+P-D-R \pm \Delta s
$$

Where $\mathrm{I}$ is the irrigation amount $(\mathrm{mm}), \mathrm{P}$ is the precipitation $(\mathrm{mm}), \mathrm{D}$ is the deep percolation $(\mathrm{mm})$ and $\Delta \mathrm{s}$ is the change of soil water depth $(\mathrm{mm})$ between two irrigations at the root zone and R is the surface runoff $(\mathrm{mm})$. Due to existing of plot's borders, no surface runoff occurred; therefore R was ignored in Equation 3. Deep percolation $\mathrm{D}$ was also ignored because no excess water was applied beyond that needed to reach FC (Field Capacity).

Soil evaporation (E) beneath the winter barley canopy was estimated by daily weighing of 16 micro-lysimeters (MLS), which were placed in plots between two rows. MLS contain small isolated volumes of bare soil mounted flush with or slightly above the soil surface (Daamen \& Simmonds, 1996) and these were weighed daily (or more frequently) to determine water loss using electronic balance with $\pm 0.001 \mathrm{~kg}$ precision. The MLS cylinders dimension were $300 \mathrm{~mm}$ in length, $110 \mathrm{~mm}$ diameter and $2 \mathrm{~mm}$ wall thickness. They were made of PVC tube and the bottom with the lid closed. To make soil moisture in the MLS similar to the field conditions, before each irrigation event, the MLS were taken away from plots and water was added to the cylinder until the MLS's soil moisture reached FC, and then they were replaced in their positions again after irrigation. The crop transpiration (T) was determined by subtracting the amount of evaporation (E) from the crop evapotranspiration (ET).

Water use efficiency was estimated by the equation 4 (Hussain \& Al-Jaloud, 1995):

$$
W U E=\frac{Y}{E T}
$$

Where WUE is the water use efficiency $\left(\mathrm{kg} \mathrm{m}^{-3}\right), \mathrm{Y}$ is the seed yield $\left(\mathrm{kg} \mathrm{m}^{-2}\right)$ and ET is the evapotranspiration (m), calculated as in Eq. 3 .

In the study area, the most rainfall occurs in winters, so the soil surface was usually wet during winter and assumed that the soil water content reduction was equal to the reference evapotranspiration (Farshi et al., 1987; Shabani et al., 2013). Soil water contents before rainfall were measured using the water balance equation. Reference evapotranspiration was estimated by Penman-Monteith equation (Allen et al., 1998) calibrated by Razzaghi and Sepaskhah (2012) for semi-arid environments in the study area. Figure 1 shows cumulative applied irrigation water at each irrigation event for different irrigation treatments and rainfall in 2011-2012 and 
2012-2013. Total amounts of rainfall were 335 and $390.5 \mathrm{~mm}$ in 2011-2012 and 2012-2013, respectively.

Ammonium phosphate at a rate of $100 \mathrm{~kg} \mathrm{ha}^{-1}$ was mixed with the soil at the plowing stage. Urea total requirement $\left(200 \mathrm{~kg} \mathrm{ha}^{-1}\right)$ was applied in winter and spring at two different times, i.e., before stem elongation and at the flowering stage.

Straw and grain $\mathrm{N}$ concentration (related protein) was determined by Kjeldahl digestion method as indicated in FAO guide to laboratory establishment for plant nutrient analysis (FAO, 2008). Before harvest, plant height and after harvest, seed yield, above ground dry matter and 1000-grain weight were determined. Plants were harvested from the five central rows with $1.0 \mathrm{~m}$ distance from edges and seeds were separated from straw and weighed. Multiple relationships were identified in relation to barley yield.

\subsection{Statistical Analysis}

For detecting suitability of analysis of variance (ANOVA) related to the data, the normality test based on Kolmogorov-Smirnov (KS) goodness of fit and quartile-quartile plot (q-q plot) was done on residuals of the ANOVA model. The normality test showed no significant deviance from the normal distribution for all measured treatments. After carrying out the ANOVA, means of interaction effects between deficit irrigation and sowing date were evaluated by the least significant means method (LSM or LSMeans) using SAS, version 9.3. The graphs were developed using Microsoft EXCEL. Since these experiments were carried out over two years (2011-2012 and 2012-2013), the combined analysis of variance (ANOVA) taking the effect of year as a random effect were applied using the general linear model (GLM) procedure of SAS.

\section{Results and Discussion}

Table 2 gives the results of the combined ANOVA, in which the effect of block within year is extracted. On the other hand, the interaction between year and two other effects (sowing dates and irrigation regimes) were significant for most of the barley traits. Therefore the analyses of data were carried out separately for each of the two years. In addition, for better assessment related to interaction of two factors (sowing dates and irrigation regimes), multiple mean comparisons of their interaction were performed. Comparing amount of rainfall in two separated growing seasons showed that the spring precipitation of the second year (2012-2013) was larger and most of the measured traits had larger values in the second year.

\subsection{Evapotranspiration}

Results of analysis of variance based on the combination data of two years of the experiment showed that the effect of all variation sources related to evapotranspiration were significant (Table 2). The evapotranspiration of the second year was larger than the first year and difference between evapotranspiration in two years was significant. Deficit irrigation caused the evapotranspiration to decrease by $18.8 \%, 36 \%$ and $61.3 \%$ at the $0.75 \mathrm{FI}$, $0.5 \mathrm{FI}$ and dry land farming treatments, respectively, during the first year (2011-2012) and the ET reduction were $16.3,30.1$ and $48.2 \%$ respectively during the second year (2012-2013) compared with full irrigation levels (Figure 3). The largest evapotranspiration rates were 667.5 and $730.9 \mathrm{~mm}$ which occurred at $\mathrm{T} 1\left(23^{\text {th }}\right.$ October) and the smallest were 586.2 and $655.2 \mathrm{~mm}$ at $\mathrm{T} 4\left(6^{\text {th }}\right.$ December $)$ in the first and second years, respectively. Obviously, as the applied irrigation water was decreased, the evapotranspiration rate was smaller. 


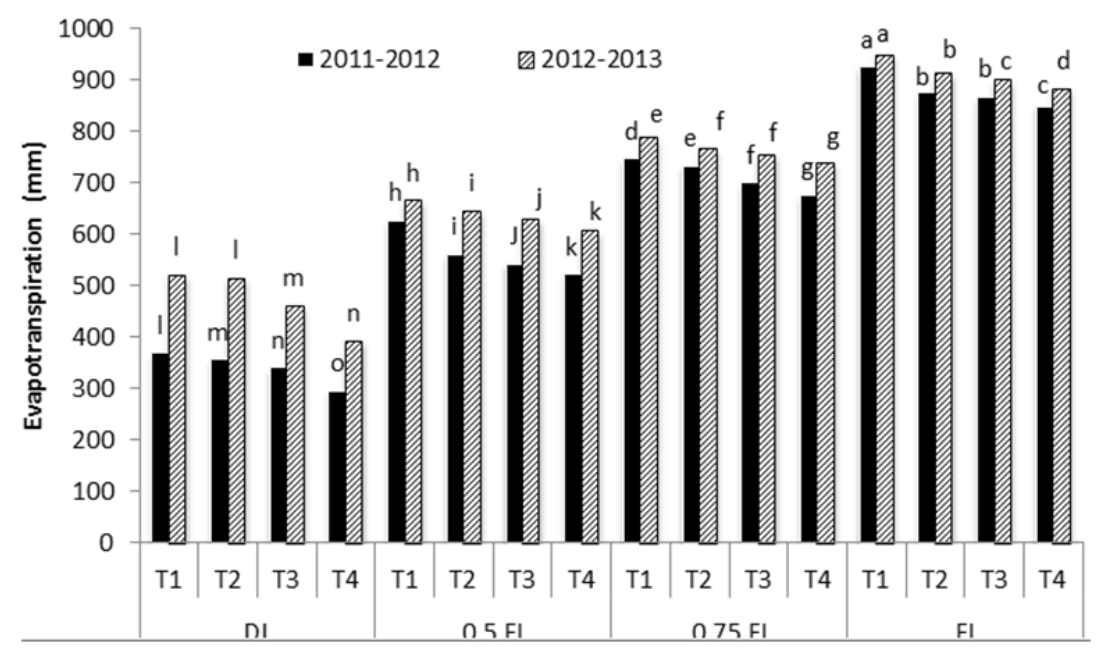

Figure 3. Mean comparison of evapotranspiration in two consecutive years

Note. The means with the same letters are not significantly different based on lsmeans method.

\subsection{Plant Height}

The effect of year on plant height was not significant (Table 2), but its interaction with the main plot factor (irrigation) was significant. The main effect of irrigation and sowing date and also their interaction on plant height were significant. In both years of experiment, deficit irrigation reduced plant height (Table 3). Maximum plant height was achieved in full irrigation at $\mathrm{T} 1$ and was 68.5 and $65 \mathrm{~cm}$ for the first and second year, respectively, and the lowest heights were related to dry land faming (37.5 and $43.6 \mathrm{~cm}$ for the first and second year, respectively). Regarding the sowing date, the higher plant height occurred in $\mathrm{T} 1$ in comparison to other sowing dates, with the last sowing date (T4-Dec 6) with the smallest plant height of barley (Table 3).

Table 2. Combined ANOVA for measured traits

\begin{tabular}{|c|c|c|c|c|c|c|c|c|c|}
\hline Source & $\mathrm{DF}$ & $\begin{array}{l}\text { Height } \\
\text { (cm) }\end{array}$ & $\begin{array}{l}1000 \text { Grain Weight } \\
\text { (gr) }\end{array}$ & $\begin{array}{l}\text { Dry Matter } \\
\left(\mathrm{Mg} \mathrm{h}^{-1}\right)\end{array}$ & $\begin{array}{c}\text { Yield } \\
\left(\mathrm{Mg} \mathrm{h}^{-1}\right)\end{array}$ & Harvest Index & $\begin{array}{c}\text { Straw Protein } \\
(\%)\end{array}$ & $\begin{array}{c}\text { Grain protein } \\
(\%)\end{array}$ & $\begin{array}{c}\text { WUE } \\
\left(\mathrm{kg} \mathrm{m}^{-3}\right) \\
\end{array}$ \\
\hline Year $(\mathrm{Y})$ & 1 & $0.78^{\text {ns }}$ & $21.67 * *$ & $46.82 * *$ & $1.02^{\mathrm{ns}}$ & $43375.5^{* *}$ & $3.65^{*}$ & $4.98^{\mathrm{ns}}$ & $0.141^{* *}$ \\
\hline Error1 & 4 & 37.72 & 5.86 & 1.56 & 0.22 & 0.0014 & 0.88 & 2.5 & 0.006 \\
\hline Irrigation (I) & 3 & $1376.48^{* *}$ & $571.48 * *$ & $363.14 * *$ & $112.34 * *$ & $0.13 * *$ & $11.45^{* *}$ & $16.76 * *$ & $0.725 * *$ \\
\hline Y*I & 3 & $196.01^{* *}$ & $0.18 * *$ & $9.75^{* *}$ & $3.16 * *$ & $0.0041^{\mathrm{ns}}$ & $3.45^{\mathrm{ns}}$ & $7.11 *$ & $0.053^{* *}$ \\
\hline Error2 & 12 & 10.14 & 2.69 & 0.58 & 0.36 & 0.0044 & 0.79 & 1.89 & 0.068 \\
\hline Sowing $(\mathrm{S})$ & 3 & $506.68 * *$ & $12.39 * *$ & $82.21 * *$ & $15.44^{* *}$ & $0.0007^{\mathrm{ns}}$ & $9.45 * *$ & $9.93 * *$ & $0.200 * *$ \\
\hline$I * S$ & 9 & $32.33 * *$ & $17.36^{* *}$ & $2.46^{\mathrm{ns}}$ & $0.5^{* *}$ & $0.0042^{\mathrm{ns}}$ & $1.65^{\mathrm{ns}}$ & $2.34^{\mathrm{ns}}$ & $0.006^{\mathrm{ns}}$ \\
\hline $\mathrm{Y} * \mathrm{~S}$ & 3 & $0.88^{\mathrm{ns}}$ & $0.04 * *$ & $2.96^{\mathrm{ns}}$ & $0.53 * *$ & $0.00269^{\text {ns }}$ & $1.34^{\text {ns }}$ & $2.98^{\mathrm{ns}}$ & $0.015^{\mathrm{ns}}$ \\
\hline $\mathrm{Y} * \mathrm{I} * \mathrm{~S}$ & 9 & $1.87^{\mathrm{ns}}$ & $0.27 * *$ & $2.02^{\mathrm{ns}}$ & $0.2^{* *}$ & $0.0053^{*}$ & $0.98^{\mathrm{ns}}$ & $3.12^{\mathrm{ns}}$ & $0.005^{\mathrm{ns}}$ \\
\hline Error3 & 48 & 6.05 & 4.74 & 1.33 & 0.31 & 0.002402 & 0.68 & 1.02 & 0.007 \\
\hline$\% \mathrm{CV}$ & & 9.89 & 8.83 & 10.43 & 11.81 & 11.87 & 9.62 & 6.67 & 12.44 \\
\hline
\end{tabular}

Note. $* * *$ and ns indicate $5 \%, 1 \%$ significant levels and not significant, respectively. 
Table 3. Interaction mean comparison of irrigation regimes and sowing dates related to plant height, 1000 grain weight and dry matter of barley

\begin{tabular}{|c|c|c|c|c|c|c|c|c|c|c|c|c|c|c|c|c|c|c|c|c|c|}
\hline \multirow[b]{2}{*}{ imigation } & \multirow[b]{2}{*}{ sowing } & \multicolumn{4}{|c|}{ Plant height $(\mathrm{cm})$} & \multicolumn{4}{|c|}{1000 grain weight (gr) } & \multicolumn{4}{|c|}{ Dry matter $\left(\mathrm{Mg} \mathrm{h}^{-1}\right)$} & \multicolumn{4}{|c|}{ Grain yield $\left(\mathrm{Mg} \mathrm{h}^{-1}\right)$} & \multicolumn{4}{|c|}{ Harvest index } \\
\hline & & \multicolumn{2}{|c|}{$\begin{array}{l}\text { First } \\
\text { year }\end{array}$} & \multicolumn{2}{|c|}{$\begin{array}{c}\text { Second } \\
\text { Year }\end{array}$} & \multicolumn{2}{|c|}{$\begin{array}{c}\text { First } \\
\text { year }\end{array}$} & \multicolumn{2}{|c|}{$\begin{array}{c}\text { Second } \\
\text { year }\end{array}$} & \multicolumn{2}{|c|}{$\begin{array}{l}\text { First } \\
\text { year }\end{array}$} & \multicolumn{2}{|c|}{$\begin{array}{c}\text { Second } \\
\text { year }\end{array}$} & \multicolumn{2}{|c|}{$\begin{array}{l}\text { First } \\
\text { year }\end{array}$} & \multicolumn{2}{|c|}{ Second year } & \multicolumn{2}{|c|}{$\begin{array}{l}\text { First } \\
\text { year }\end{array}$} & \multicolumn{2}{|c|}{$\begin{array}{c}\text { Second } \\
\text { year }\end{array}$} \\
\hline \multirow{4}{*}{ FI } & $\mathrm{T}^{*}$ & 68.50 & a & 66.00 & $\mathrm{a}$ & 29.42 & $a b c$ & 28.83 & $a b$ & 18.71 & a & 17.35 & $\mathrm{a}$ & 8.79 & a & 07 & a & 0.47 & abcd & 41 & $\mathrm{a}$ \\
\hline & $\mathrm{T} 2$ & 64.07 & $a b$ & 61.40 & $\mathrm{~b}$ & 27.96 & $a b c d$ & & $a b c$ & 14.64 & $\mathrm{~b}$ & & $\mathrm{~b}$ & & & & & 48 & bcd & & a \\
\hline & $\mathrm{T} 3$ & 59.70 & bcd & 56.70 & $\mathrm{~cd}$ & 30.99 & $a b$ & 29.54 & $a$ & 14.12 & b & 15.13 & b & 6.84 & $\mathrm{bc}$ & 628 & & .49 & $a b c$ & & a \\
\hline & $\mathrm{T} 4$ & .90 & $\mathrm{~cd}$ & 55.90 & $\mathrm{~cd}$ & & $\mathrm{a}$ & & a & & 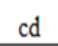 & & c & 6.16 & & & & & a & & $\mathrm{a}$ \\
\hline \multirow{4}{*}{$0.75 \mathrm{FI}$} & - & 3 & $a b$ & 61 & $\mathrm{~b}$ & 26.62 & cde & 25.02 & had & 14.25 & $\mathrm{~b}$ & 5.02 & $\mathrm{~b}$ & 7.05 & $b c$ & & & 47 & abcd & & 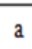 \\
\hline & $\mathrm{T}$ & & $b c$ & & $\mathrm{bc}$ & & & & . & & 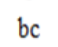 & & c & & & & & & $\mathrm{cd}$ & & \\
\hline & $\mathrm{T}$ & 57 & $\mathrm{~cd}$ & 55.80 & $\mathrm{~cd}$ & 28.64 & abcd & 27.49 & $a b c$ & 10.63 & de & 12.87 & c & 5.70 & $\mathrm{~cd}$ & & & 48 & abcd & & $a_{0}$ \\
\hline & $\mathrm{T}$ & & $\mathrm{d}$ & 54.17 & d & 26.29 & cde & 25.06 & bcd & 10.83 & de & 10.06 & de & & $\mathrm{e}$ & & & 50 & $a b$ & & $a b$ \\
\hline \multirow{4}{*}{$0.5 \mathrm{FI}$} & $\mathrm{T}$ & & $b c$ & 5 & $\mathrm{bc}$ & 23.29 & ef & 22.59 & $\mathrm{de}$ & 13.03 & bcd & 13.13 & $\mathrm{c}$ & 6.15 & bcd & & & 49 & $a b c$ & & - \\
\hline & $\mathrm{T} 2$ & & $\mathrm{~cd}$ & 55.30 & $\mathrm{~d}$ & 23.47 & ef & 22.06 & $\mathrm{de}$ & 10.87 & $\mathrm{de}$ & 12.48 & c & 4.86 & $\mathrm{de}$ & & & 48 & abcd & & \\
\hline & T3 & .53 & $\mathrm{e}$ & 45.83 & $\mathrm{fg}$ & 27.31 & bcd & 26.77 & $a b c$ & 8.74 & ef & 10.58 & $\mathrm{~d}$ & 4.18 & $\mathrm{e}$ & 4. & & .54 & $\mathrm{a}$ & & a \\
\hline & $\mathrm{T} 4$ & 46.60 & e & 43.43 & $\mathrm{~g}$ & 24.79 & $\mathrm{de}$ & 23.80 & $\mathrm{~cd}$ & 7.88 & $\mathrm{f}$ & 9.78 & $\mathrm{de}$ & 3.92 & $\mathrm{e}$ & & & 42 & bcd & & $\mathrm{a}$ \\
\hline \multirow{4}{*}{$\mathrm{DL}$} & - & & $\mathrm{f}$ & 52.60 & $\mathrm{de}$ & 19.93 & gf & 19.01 & ef & 5.21 & $\mathrm{~g}$ & 8.76 & $\mathrm{e}$ & 1.95 & $\mathrm{f}$ & & & 37 & $\mathrm{de}$ & & \\
\hline & $\mathrm{T} 2$ & 41.13 & $\mathrm{f}$ & 50.13 & $\mathrm{e}$ & 19.55 & gf & 18.96 & ef & 4.73 & $\mathrm{~g}$ & 8.87 & e & 1.82 & $\mathrm{f}$ & 2.3 & & 0.38 & cde & 0.2 & \\
\hline & T3 & 39.33 & $\mathrm{f}$ & 48.67 & ef & 18.16 & $\mathrm{~g}$ & 17.07 & $\mathrm{f}$ & 3.21 & $\mathrm{~g}$ & 7.19 & $\mathrm{f}$ & 0.91 & $\mathrm{f}$ & & & & ef & & \\
\hline & $\mathrm{T} 4$ & 37.60 & $\mathrm{f}$ & 43.60 & $\mathrm{~g}$ & 16.22 & $\mathrm{~g}$ & 15.89 & $\mathrm{f}$ & 3.76 & $\mathrm{~g}$ & 4.92 & $\mathrm{~g}$ & 0.74 & f & 1.61 & $\mathrm{~g}$ & 0.22 & $\mathrm{f}$ & 0.33 & 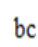 \\
\hline
\end{tabular}

Note. The means with the same letters are not significantly different based on lsmeans method of SAS software, *(sowing: T1-Oct 23, T2-Nov 6, T3-Nov 22, and T4-Dec 6).

Supplying appropriate amount of water at the root zone has a positive impact on vegetative growth of plants, especially on plant height. Reduction of plant height under deficit irrigation may be due to reduction in cell elongation as a result of water stress. Furthermore, plant growth might have been retarded with smaller stomatal conductance, reduction in photosynthesis rate, and ion toxicity (Ashraf and Mcneilly, 2004; Mohammadi et al., 2012). Lower plant height might be caused from the weather condition (cold weather) in time of sowing since the primary growth of a plant is affected by late a sowing date. Similar results were reported by Shabani et al. (2013) and Dastan et al. (2011).

\subsection{0-Grain Weight}

Results of analysis of variance showed significant effect for all treatments (main effects) and their interactions (Table 2). In both growing seasons, 1000-grain weights were decreased by reducing availability of water at the root zone in the soil profile, while full irrigation showed largest 1000-grain weights in compare to other water regimes, but it is worthwhile to state that full irrigation and 0.75 FI regimes did not show significance level of differences (Table 3). The smallest 1000-grain weights was obtained in dry land farming which showed significant differences comparing with other water regimes. In all water level treatments $(0.5 \mathrm{FI}, 0.75 \mathrm{FI}$, and FI) late sowing date decreased 1000-grain weight while under dry land farming the results was observed conversely in both years. Considering the interaction means for 1000-grain weight, there were no significant differences between sowing dates under different water regimes in both years. Araya et al. (2010) reported that the 1000 -grain weight for planting date of July $4^{\text {th }}$ (early sowing), July $12^{\text {th }}$ (normal sowing) and July $22^{\text {th }}$ (late sowing) were 55-61, 50-56 and 43-49 gr, respectively. The 1000-grain weights for irrigated and dry land farming with planting date of July $4^{\text {th }}$ were almost equal. This shows that seed weight decreases with a decrease in water availability which may have implicated grain yield and harvest index of barley.

The 1000-grain weights were measured in full irrigation level and dry land farming interacted with T4 sowing date (Table 3). Results show the largest (31.77 and 30.82 gr) and the lowest smallest (16.22 and 15.89 gr) for full irrigation level and dry land in the first and second years, respectively. Nagaz et al. (2008) obtained a decline in production in barley 1000-grain weight with a reduction in water supply levels from fully irrigated field (100\% $\mathrm{ET}_{\mathrm{c}}$ ) to moderately deficit irrigated field $\left(50 \% \mathrm{ET}_{\mathrm{c}}\right)$. The reduction in 1000-grain weight was attributed to grain filling failure as a result of decreasing in water supply.

\subsection{Dry Matter}

Factors affecting the dry matter of barley such as main effect of year, irrigation levels and sowing times in ANOVA analysis table were significant but the only interaction effect of these factors was the year by irrigation 
interaction (Table 2). Comparison of full irrigation regime with deficit irrigation showed the decrease of dry matter by $15.7 \%, 31.2 \%$ and $71.3 \%$ at $0.75 \mathrm{FI}$ and $0.5 \mathrm{FI}$, and dry land treatments, respectively in first year, and by $15.4 \%, 24.6 \%$ and $51.2 \%$ at $0.75 \mathrm{FI}$ and $0.5 \mathrm{FI}$, and dry land treatments, respectively in second year. It is clearly indicated the results clearly indicate that later sowing dates have a negative effect on dry matter (Table 3 ). Under all water regimes in both years, T1 sowing date showed largest dry matter while the smallest was in T4. Largest dry matter, with a significant impact level, was obtained for full irrigation interacted with T1 sowing date (18.7 and $17.35 \mathrm{Mg} \mathrm{ha}^{-1}$ for the first and second year respectively), and the smallest was obtained for dry land farming interacted with $\mathrm{T} 4$ sowing date (3.76 and $4.92 \mathrm{Mg} \mathrm{ha}^{-1}$ for the first and second years, respectively).

Nagaz et al. (2008) obtained the largest yield and biomass at full irrigation $\left(100 \% \mathrm{ET}_{\mathrm{c}}\right)$ but it was not significantly larger than the plants treated with the mild water stress $\left(85 \% \mathrm{ET}_{\mathrm{c}}\right)$.

\subsection{Grain Yield}

The factors affecting grain yield indicated that except of year (main effect), all other main and interaction effects of source of variations in ANOVA analysis table were significant (Table 2). Deficit irrigation decreased grain yield of the barley by $81 \%$ and $61 \%$ for dry land farming, $33 \%$ and $28 \%$ for $0.5 \mathrm{FI}, 16 \%$ and $15 \%$ for $0.75 \mathrm{FI}$ in the first and second year, respectively. Results showed that deficit irrigation at $0.75 \mathrm{FI}$ level has the smallest reduction in grain yield in comparison to FI, so decreasing of irrigation water up to $75 \%$ of full irrigation can be as alternative in a farm with limited water to get suitable grain yield. Table 3 shows mean comparisons of grain yield in two growing seasons for interaction of irrigation regimes and sowing dates. Under all irrigation regimes, late sowing of barley reduced grain yield. In all irrigation treatments the largest barley yields were obtained at full irrigation interacted with $\mathrm{T} 1$ by 8.79 and $7.07 \mathrm{Mg} \mathrm{ha}^{-1}$ in the first and second year, respectively, and the smallest occurred in dry land farming interacted with $\mathrm{T} 4$ by 0.74 and $1.61 \mathrm{Mg} \mathrm{ha}^{-1}$ in the first and second year, respectively. The relationship between the irrigation ratio in full irrigation treatments and grain yield in both consecutive years are presented in Figure 4 as shown by Equations 5 and 6 .

$$
\begin{gathered}
Y_{1(2012)}=1.5225+5.8889(I R) ;\left(R^{2}=0.99\right) \\
Y_{2(2013)}=2.2631+4.2065(I R) ;\left(R^{2}=0.99\right)
\end{gathered}
$$

Where: $\mathrm{Y}_{1}$ and $\mathrm{Y}_{2}$ are the yields $\left(\mathrm{Mg} \mathrm{ha}^{-1}\right)$ in first and second years, respectively and IR is the Irrigation ratio. The regression line slopes of the equations for the two years are significantly different which indicates the importance impact of precipitation and weather conditions on barley grain yield. Figure 4 also shows an interaction between years and irrigation conditions. Figure 5 shows the relationship between barley grain yield and total evapotranspiration with regression line slope of 0.0112 in the first year (Equation 7) and 0.0096 in the second year (Equation 8$)$. This indicates that there is no significant differences $(p>0.05)$ in two consecutive years. The regression lines' constants in Equations 7 and 8 reveal no significant difference as well, therefore a general relationship between yield and evapotranspiration for all data for both years as given by Equation 9 .

$$
\begin{gathered}
Y_{1}=-2.143+0.0112\left(E T_{1}\right) ;\left(R^{2}=0.91\right) \\
Y_{2}=-2.06+0.0096\left(E T_{2}\right) ;\left(R^{2}=0.89\right) \\
Y=-1.911+0.0101(E T) ;\left(R^{2}=0.89\right)
\end{gathered}
$$

Where: $\mathrm{Y}_{1}, \mathrm{Y}_{2}$ and $\mathrm{ET}_{1}$ and $\mathrm{ET}_{2}$ are the barley yield $\left(\mathrm{Mg} \mathrm{ha}^{-1}\right)$ and evapotranspiration $(\mathrm{mm})$ in the first and second year, respectively. 


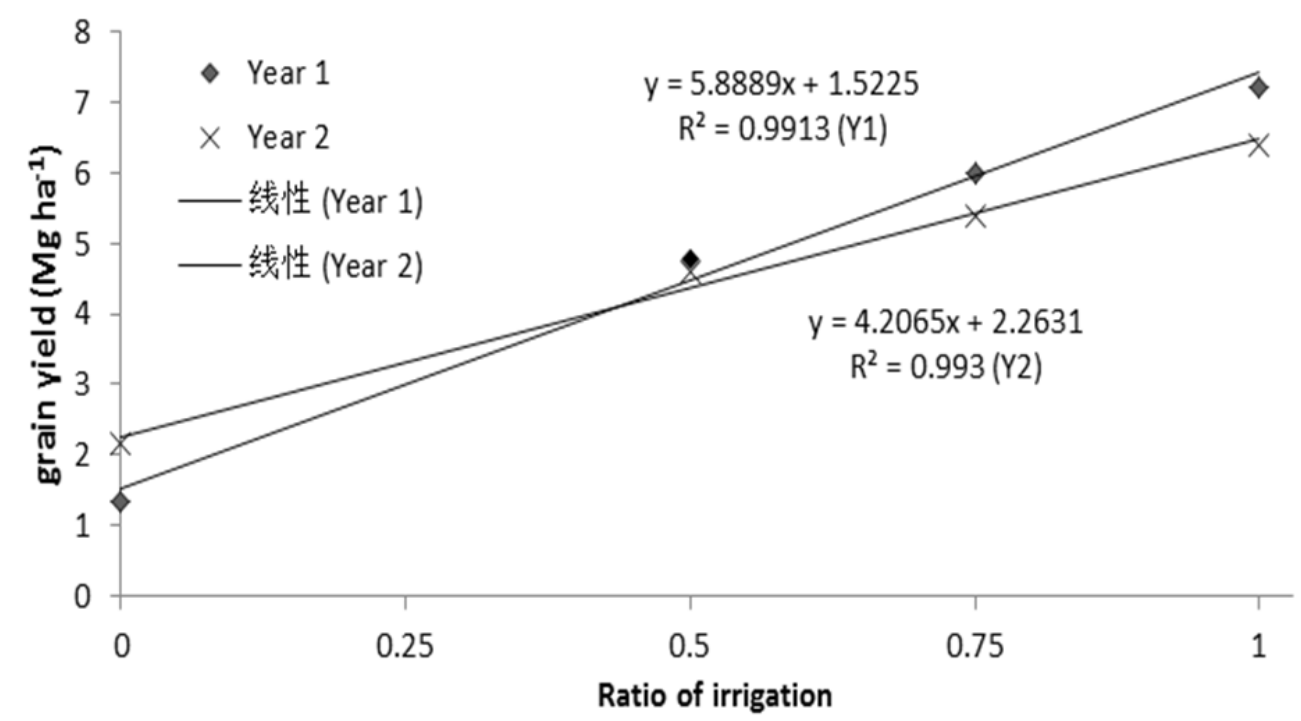

Figure 4. Relationship between amount of irrigation and barley grain yield under two consecutive growing years

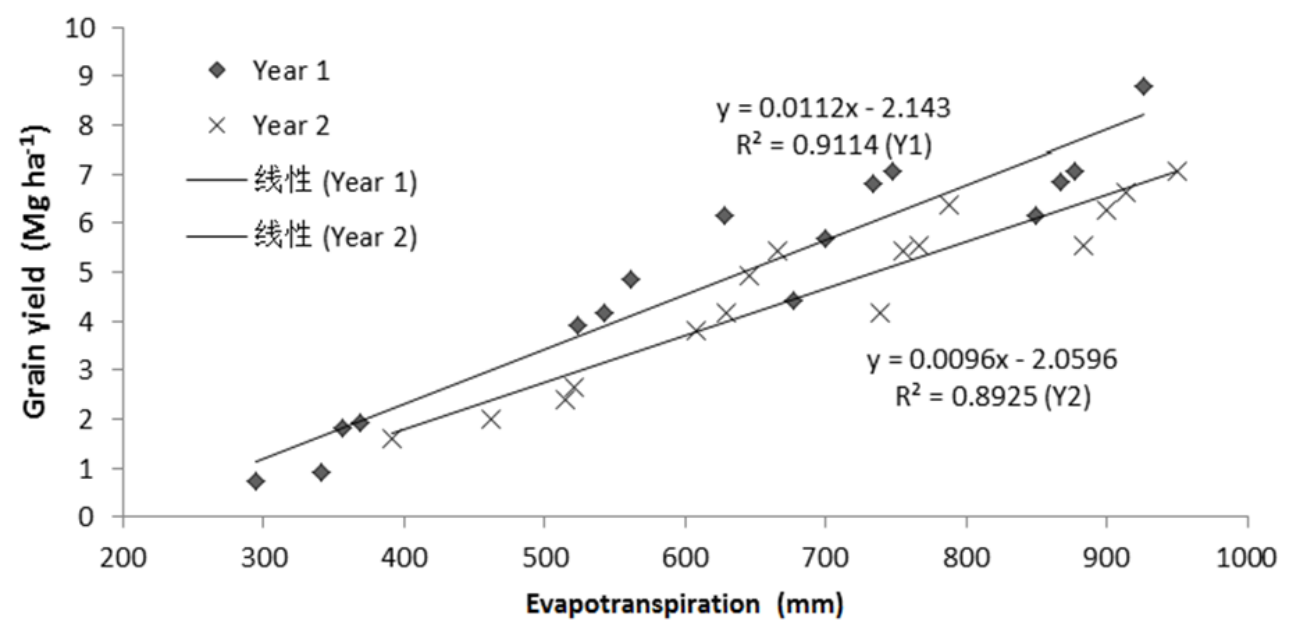

Figure 5. Relationship between amount of evapotranspiration and barley grain yield under two consecutive growing years

Therefore, largest evapotranspiration would result in largest grain yield. These results indicate a need to establish a precise sowing date in the field management to get the largest yield under water deficit and dry land farming of barley. Similar results have been reported by Albrizio et al. (2010), Kalaji et al. (2012) for barley, Shabani et al. (2013) for rapeseed and Howell et al. (1998) and Zhang and Oweis (1999) for wheat. Araya et al. (2010) reported that the largest amount of barley grain yield and biomass was obtained a sowing date on July 4 rather than 12 and 22 July during two years (2008 and 2009) experiment. In a study by Albrizio et al. (2010), yield of barley varied significantly in relation to the amount of available water. The relation between dry matter and transpiration was determined as the Eq. 10.

$$
D M=2.1898(T)-0.0201 ;\left(R^{2}=0.81\right)
$$

Where $\mathrm{DM}$ is dry matter $(\mathrm{Mg})$ and $\mathrm{T}$ is transpiration $(\mathrm{mm})$.

\subsection{Harvest Index}

Results of combined analysis of variance for harvest index showed significant difference for main effect of year and irrigation. Also a significant difference was found in the three way interaction of year with irrigation and sowing time. However all other sources of variation were not significant (Table 2). Harvest index in the second year was smaller than the first year in general (Table 3). This is probably due to the frostbite that occurred the 
second year (Figure 2). Based on the analyzed data, significant differences between deficit irrigation levels $(0.75$ and 0.5 full irrigation) and full irrigation were very small, while the differences between dry land farming and irrigation regimes were large in both years (Table 3). Dry land farming significantly showed smaller harvest index compare to irrigation regimes. Different time of sowing dates showed similar results for harvest index in all water irrigation levels.

High harvest index (HI) expresses successful plant reproduction and yield in terms of reproductive functions and assimilate partitioning towards reproduction (Blum, 2009). Araya et al. (2010) reported that early planting (July 4) and irrigation, improved the harvest index when compared to late planting (July 22). Harvest index may decrease due to shortening of the canopy cover duration resulting in a short grain filling period (Hsiao et al., 2009). Albrizio et al. (2010) reported no significant differences for different water regimes. On the other hand, Dastan et al. (2011) reported the largest and smallest grain yields and harvest indexes for Nov 26, and Dec 11, sowing dates, respectively.

\subsection{Grain and Straw Protein Content}

Results showed that the effect of year on protein content of straw was significant, but its effect on grain protein was not (Table 2). Different Irrigation levels showed significant effect on both straw and grain protein content of barley, while year by irrigation interaction was just significant for grain protein content. The analysis of variance indicates significant effect of sowing time on both straw and grain yield. Using slice statement of SAS software, the significance level of comparison among sowing dated within each irrigation regime was carried out. Except for the full irrigation regime during the second year, there was no significant difference among four sowing dates (Table 4). The difference among the four sowing dates for each irrigation regime related to grain protein content of barley was significant in both years. Results of mean comparison for the interaction effect of irrigation by sowing date are also presented in Table 4. Result indicates that the amount of protein in barley grain and straw was increased with drought severity for both years (Table 4). Late sowing of the barley seeds resulted in larger production of protein in grains and straw. The largest protein content of straw $(5.35 \%$ and $4.88 \%$ in first and second year, respectively) and barley grains (14.53\% and $14.68 \%$ in first and second year, respectively) were observed in dry land farming due to late sowing date of 6 December. The smallest protein contents for straw $(1.84 \%$ and $1.64 \%)$ and grain $(5.4 \%$ and $4.9 \%)$ were achieved in the first and second year, respectively by full irrigation method due to early time of sowing at 23 October. The results of the study carried out by Qi et al. (2005) indicated that grain protein content increased as the sowing date was postponed and it was significantly affected by the sowing date. In their research sowing date in 26 March had smallest, while sowing date in 25 April had the highest largest, content of protein in the barley grain. Darby and Zucker (2003) stated that a delay in planting resulted in larger content of protein in forage. Nass et al. (1975) reported that late seeding of wheat, oats and barley in the spring resulted in large yield reductions, which involved decreased hectoliter weight, 1,000 -kernel weight and grain protein yield. Based on these results greater protein and malt quality could be obtained by proper management of barley field by controlling the amount of water and suitable date of sowing. So that, the interaction effect of deficit irrigation and sowing date must be considered as a profitable methods in order to get better malt quality and minimum the decrease in yield. With respect to the larger protein content and lower reduction in grain yield, deficit irrigation of about $0.75 \mathrm{FI}$ and a later sowing date (from 23 October) is suggested for Iranian farmer in the south part of Iran.

Table 4. Mean comparison for grain and straw protein in both growing years

\begin{tabular}{|c|c|c|c|c|c|c|c|c|c|}
\hline \multirow{2}{*}{ Irrigation } & \multirow{2}{*}{ Sowing date } & \multicolumn{4}{|c|}{ Straw protein } & \multicolumn{4}{|c|}{ Grain Protein } \\
\hline & & \multicolumn{2}{|c|}{ First year } & \multicolumn{2}{|c|}{ Second year } & \multicolumn{2}{|c|}{ First year } & \multicolumn{2}{|c|}{ Second year } \\
\hline \multirow{4}{*}{ FI } & $\mathrm{T} 1$ & 1.84 & $\mathrm{~g}$ & 1.64 & $\mathrm{~g}$ & 5.4 & $\mathrm{k}$ & 4.9 & $\mathrm{k}$ \\
\hline & $\mathrm{T} 2$ & 2.39 & fg & 2.31 & fg & 7.15 & $\mathrm{~g}$ & 6.93 & $\mathrm{i}$ \\
\hline & T3 & 2.77 & efg & 2.65 & ef & 8.32 & $\mathrm{i}$ & 7.95 & $\mathrm{i}$ \\
\hline & $\mathrm{T} 4$ & 3.00 & defg & 2.85 & ef & 9.02 & $\mathrm{~h}$ & 8.64 & $\mathrm{~h}$ \\
\hline \multicolumn{2}{|c|}{ Significance level } & 0.062 & & 0.032 & & $<0.01$ & & $<0.01$ & \\
\hline \multirow{4}{*}{$0.75 \mathrm{FI}$} & $\mathrm{T} 1$ & 2.93 & defg & 2.76 & ef & 8.81 & $\overline{\mathrm{i}}$ & 8.3 & $\mathrm{~h}$ \\
\hline & $\mathrm{T} 2$ & 3.23 & cdef & 3.06 & def & 9.69 & $\mathrm{~h}$ & 9.2 & $\mathrm{~g}$ \\
\hline & $\mathrm{T} 3$ & 3.71 & bcde & 3.64 & bcde & 11.15 & $\mathrm{f}$ & 10.9 & $\mathrm{f}$ \\
\hline & $\mathrm{T} 4$ & 4.11 & abcd & 4.1 & abcd & 12.9 & $\mathrm{~d}$ & 12.3 & $\mathrm{~d}$ \\
\hline \multicolumn{2}{|c|}{ Significance level } & 0.059 & & 0.087 & & $<0.01$ & & $<0.01$ & \\
\hline $0.5 \mathrm{FI}$ & $\mathrm{T} 1$ & 3.33 & cdef & 3.12 & def & 9.92 & $\mathrm{~h}$ & 9.34 & $\mathrm{~g}$ \\
\hline
\end{tabular}




\begin{tabular}{rccccccccc} 
& T2 & 3.85 & bcde & 3.66 & bcde & 11.56 & ef & 10.98 & ef \\
& T3 & 4.07 & abcde & 4.03 & abcd & 12.78 & d & 12.1 & d \\
T4 & 4.17 & abcd & 4.59 & ab & 14.01 & c & 13.76 & c \\
\hline \multicolumn{2}{r}{ Significance level } & 0.092 & & 0.089 & & $<0.01$ & & $<0.01$ & \\
\hline \multirow{2}{*}{ Dry land } & T1 & 4.54 & abc & 3.38 & cdef & 13.03 & $\mathrm{c}$ & 10.15 & ef \\
& T2 & 4.82 & ab & 3.55 & bcde & 13.89 & $\mathrm{c}$ & 10.66 & ef \\
& T3 & 4.94 & ab & 4.31 & abc & 14.12 & b & 12.95 & $\mathrm{~b}$ \\
& T4 & 5.35 & a & 4.88 & a & 14.53 & a & 14.68 & a \\
\hline \multicolumn{2}{r}{ Significance level } & 0.105 & & 0.061 & & 0.013 & & $<0.01$ & \\
\hline
\end{tabular}

Note. Same letters in each column indicate no significant difference based on lsmeans method in SAS software. Significance level indicate the type I error for comparison of sowing dates in each irrigation regime using slice statement of SAS software.

\subsection{Water Use Efficiency}

Combined ANOVA analysis on WUE indicated that there were significant differences between the levels of irrigation and sowing dates and different growing seasons (Table 2). Significance analysis of interaction between all parameters showed that except of the interaction between irrigation levels and year, other interactions were not significant. The largest value of WUE was obtained under the different sowing dates in 0.5FI which showed no significant differences in compare to $0.75 \mathrm{FI}$ and FI treatments, while dry land farming showed largest value of WUE (Figure 6). There were 52\% and 35\% reduction of WUE at dry land farming compare to full irrigation condition in first and second year, respectively, while an increment of $3 \%$ and $2 \%$ were seen at $0.5 \mathrm{FI}$ treatments and $3 \%$ and $1 \%$ at $0.75 \mathrm{FI}$ treatments in the first and second year, respectively. Scatter plot of the irrigation levels and WUE and the trend line of their relationship showed a significant quadratic relationship between irrigation level and WUE as an independent variable with more than 0.98 coefficient of determination (Figure 7). The results indicated that by increasing the amount of irrigation from 0 to $0.5 \mathrm{FI}$, WUE is increased, but it is decreased when irrigation level increase from 0.5FI to full irrigation. The best performance of the irrigation levels related to WUE was obtained in 0.5FI. WUE was higher largest at T1 ( $23^{\text {th }}$ October) when compared to other sowing dates in all irrigation levels, but it was decreased with a late sowing date.

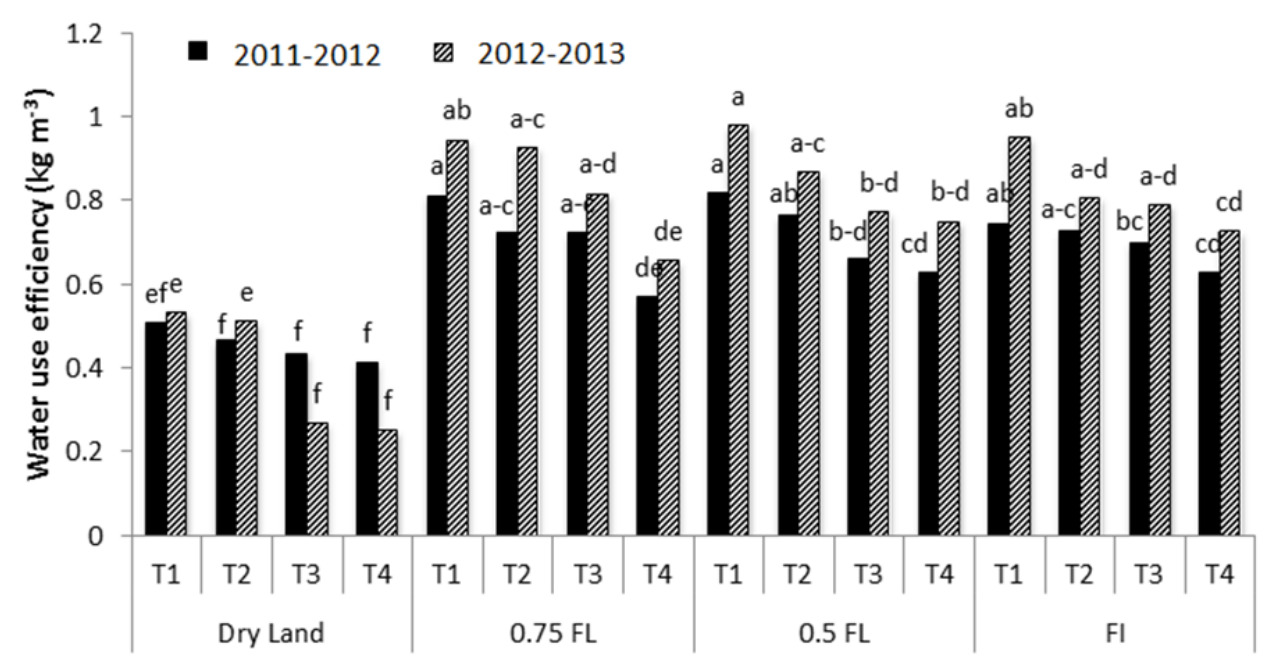

Figure 6. Mean comparison for interaction different irrigation levels with sowing dates related to water use efficiency

Note. * The means with the same letters are not significantly different based on lsmeans method. 


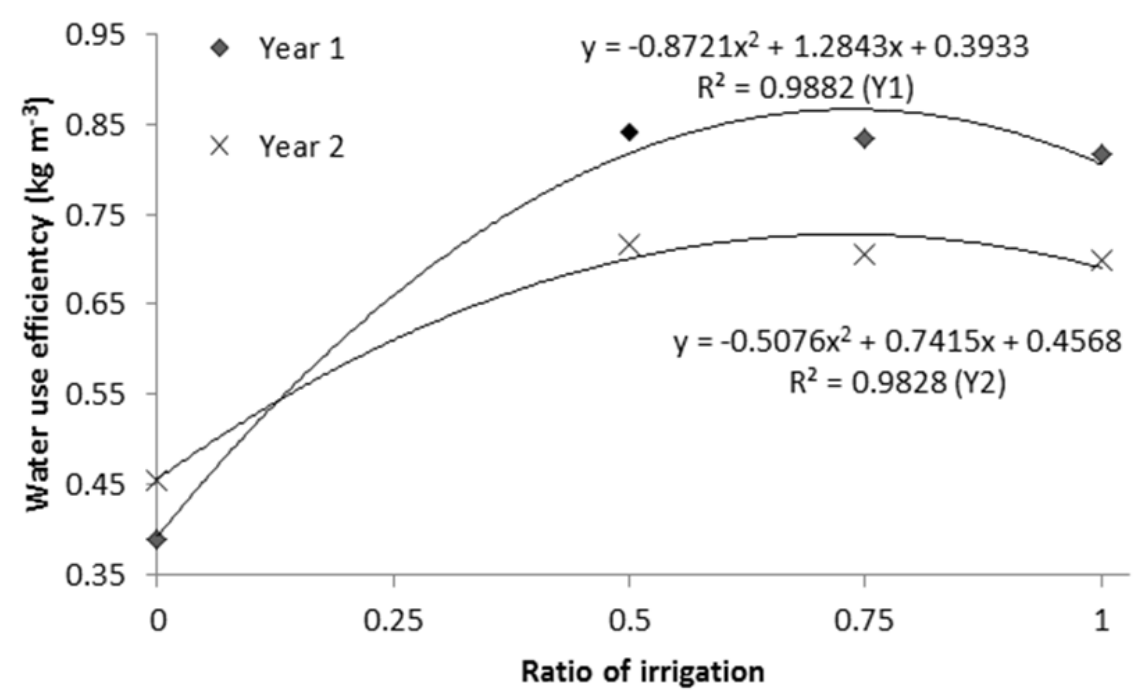

Figure 7. Relationship between amount of irrigation and water use efficiency under two consecutive growing years

Considering the achieved models (Eqs. 11, 12) for WUE in this study, the trend of WUE in related to total evapotranspiration as an independent variable showed a quadratic model fit significantly better than a linear model. Equation 11 and 12 show the quadratic relationship between evapotranspiration and WUE, with coefficient of determination equal to 0.8 and 0.7 in the first and second year, respectively (Figure 8).

$$
\begin{aligned}
& W U E_{1(2012)}=-0.7576+0.0044\left(E T_{1}\right)-0.000003\left(E T_{1}\right)^{2} ;\left(R^{2}=0.79\right) \\
& W U E_{2(2013)}=-0.6567+0.0034\left(E T_{2}\right)-0.000002\left(E T_{2}\right)^{2} ;\left(R^{2}=0.69\right)
\end{aligned}
$$

Based on Equations 11 and 12, the best performance for WUE can be estimated in 0.7FI treatment when ET is in the ranges of 700-800 mm, while ET outside of this range decreases WUE (Figures $7 \&$ 8). Albrizio et al. (2010) reported there is no significant differences between WUE and deficit irrigation levels, but with increasing the irrigation water supply, a slight average reduction of the two efficiency parameters was observed for both studied crops (wheat and barley). In rain fed conditions the decrement of water use efficiency based on biological yield $\left(\mathrm{WUE}_{\mathrm{b}}\right.$ ) were $16.2 \%$ and $14.4 \%$ in $0.5 \mathrm{FI}$ and FI treatments, while the decrement in mean water use efficiency based on grain yield (WUE $)$ were $14.2 \%$ in $0.5 \mathrm{FI}$ and $11.7 \%$ in FI, respectively (Albrizio et al., 2010).

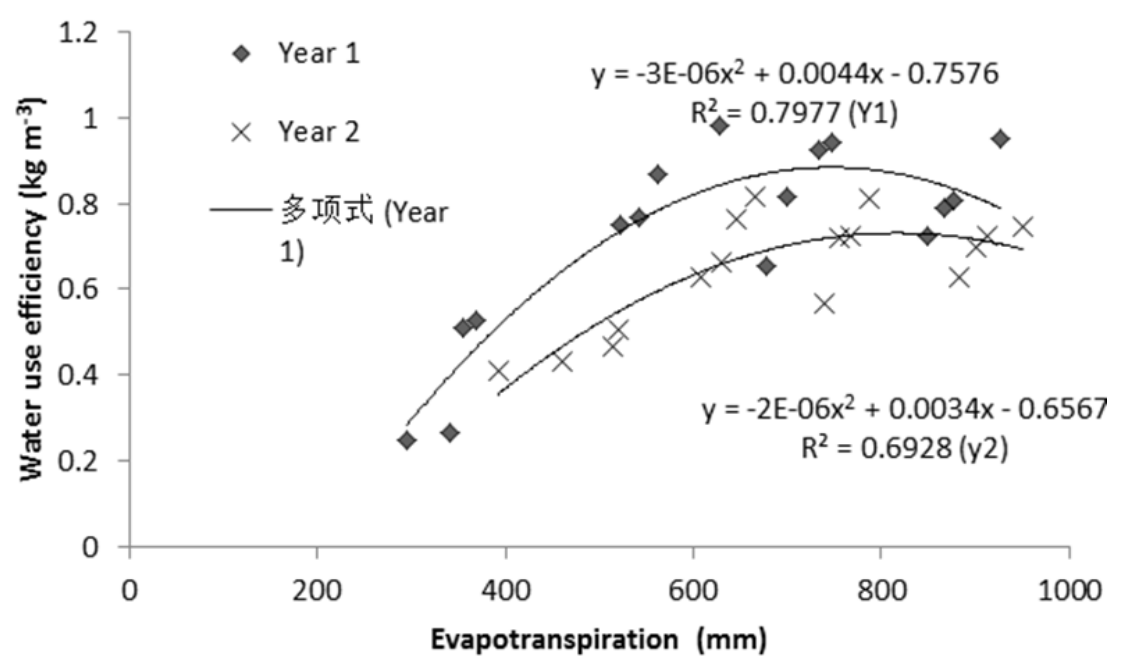

Figure 8. Relationship between amount of evapotranspiration and barley grain yield under two consecutive growing years 


\section{Conclusion}

Interaction effects of different sowing date and irrigation regimes were studied for barley. Decreasing the amount of irrigation water caused significant impact on reduction of barley grain yield and its components. The smallest amount of yield components was obtained in dry land farming. The amount of grain yield reduction at $75 \%$ of full irrigation treatment was smaller than other irrigation levels. Results indicate that $75 \%$ of full irrigation could be used as an alternative of deficit irrigation method in order to get better performance of WUE and grain yield in semi-arid region. On the other hand, changing in sowing dates could have significant impact on barley grain yield and yield related traits. Therefore, better performance of barley also depends on precise field management and time of sowing. In this study the best performance of yield and other traits were obtained in $\mathrm{T} 1\left(23^{\text {th }}\right.$ October $)$ for two consecutive year (2011-2012; 2012-2013).

The relationship between evapotranspiration and WUE showed that this relationship could be modeled as quadratic equations. This research showed an increase or decrease of evapotranspiration has significant impact on WUE based on the obtained quadratic equations, the best performance of barley related to the deficit irrigation could be achieved if $60 \%$ to $80 \%$ of full irrigation is applied. The relationship between grain yield and evapotranspiration showed a simple linear model with positive slope which indicate larger yields with larger evapotranspiration amounts, but an additional increment of evapotranspiration caused a reduction in WUE. The amount of protein in grain and straw was increased with heighten of drought severity and late sowing dates in both years. Overall, for semi-arid regions such as Iran, where the water crisis and decreasing water table depths, are the major problems and the barley is one of the main crops, there is a need to manage the best time of sowing date and amount of irrigation water. Interaction effects of different sowing dates and irrigation regimes in our study showed that the earliest sowing date (October $23^{\text {th }}$ ) and applying 0.75 of full irrigation (suggested $60 \%$ up to $80 \%$ of full irrigation) is an alternative way for barley farming in semi-arid region.

\section{References}

Acuña, T. L. B., \& Wade, L. J. (2013). Use of genotype environment interactions to understand rooting depth and the ability of wheat to penetrate hard soils. Annals of Botany, 112, 359-368. http://dx.doi.org/ $10.1093 / \mathrm{aob} / \mathrm{mcs} 251$

Albrizio, R., Todorovic, M., Matic, T., \& Stellacci, A. M. (2010). Comparing the interactive effects of water and nitrogen on durum wheat and barley grown in a Mediterranean environment. Field Crops Research, 115, 179-190. http://dx.doi.org/10.1016/j.fcr.2009.11.003

Ali, H., Afzal, M. N., Ahmad, S., \& Muhammad, D. (2009). Effect of cultivars and sowing dates on yield and quality of Gossypium hirsutum L. Crop. Journal of Food, Agriculture and Environment, 7, 244-247.

Allen, R. G., Pereira, L. S., Raes, D., \& Smith, M. (1998). Crop evapotranspiration-Guidelines for computing crop water requirements-FAO Irrigation and drainage paper 56. FAO, Rome, 300, 6541.

Amjadian, M., Farshadfar, M., \& Gholipoor, M. (2013). The effects of planting dates on the yield and yield components of corn (Zea mays L.) cultivar single cross 704 in Gorgan region. Annals of Biological Research, 4, 38-41.

Araya, A., Habtu, S., Hadgu, K. M., Kebede, A., \& Dejene, T. (2010). Test of AquaCrop model in simulating biomass and yield of water deficient and irrigated barley $(<\mathrm{i}>$ Hordeum vulgare $</ \mathrm{i}>)$. Agricultural Water Management, 97, 1838-1846. http://dx.doi.org/10.1016/j.agwat.2010.06.021

Ashraf, M., \& McNeilly, T. (2004). Salinity tolerance in Brassica oilseeds. Critical Reviews in Plant Sciences, 23, 157-174. http://dx.doi.org/10.1080/07352680490433286

Blum, A. (2009). Effective use of water (EUW) and not water-use efficiency (WUE) is the target of crop yield improvement under drought stress. Field Crops Research, 112, 119-123. http://dx.doi.org/10.1016/j.fcr.2009.03.009

Daamen, C. C., \& Simmonds, L. P. (1996). Measurement of evaporation from bare soil and its estimation using surface resistance. Water Resources Research, 32, 1393-1402.

Darby, M. R., \& Zucker, L. G. (2003). Growing by leaps and inches: creative destruction, real cost reduction, and inching up. Economic Inquiry, 41, 1-19. http://dx.doi.org/ 10.1093/ei/41.1.1

Dastan, S., Mobasser, H., Ghanbari-Malidarreh, A., Arab, R., Ghorbannia, E., \& Rahimi, R. (2011). Effects of sowing dates and CCC application on morphological traits, agronomical indices and grain yield in barley cultivars. World Applied Sciences Journal, 14, 1717-1723 
English, M., \& Raja, S. N. (1996). Perspectives on deficit irrigation. Agricultural Water Management, 32, 1-14. http://dx.doi.org/10.1016/S0378-3774 (96) 01255-3

Farshi, A. A., Feyen, J., Belmans, C., \& De Wijngaert, K. (1987). Modelling of yield of winter wheat as a function of soil water availability. Agricultural Water Management, 12, 323-339. http://dx.doi.org/10.1016/0378-3774 (87) 90007-2

Geerts, S., \& Raes, D. (2009). Deficit irrigation as an on-farm strategy to maximize crop water productivity in dry areas. Agricultural Water Management, 96, 1275-1284. http://dx.doi.org/10.1016/j.agwat.2009.04.009

Ghaemi, A. A., \& Tabarzad, A. (2014). Development of micro irrigation design software (MIDS) to optimize total project cost and hydraulic parameters. Transactions of Civil Engineering, 38, 297-307.

Hassan, R., \& Nhemachena, C. (2008). Determinants of African farmers' strategies for adapting to climate change: Multinomial choice analysis. African Journal of Agricultural and Resource Economics, 2, 83-104.

Howell, T. A., Tolk, J. A., Schneider, A. D., \& Evett, S. R. (1998). Evapotranspiration, yield, and water use efficiency of corn hybrids differing in maturity. Agronomy Journal, 90, 3-9. http://dx.doi.org/10.2134/agronj1998.00021962009000010002x

Hsiao, T. C., Heng, L., Steduto, P., Rojas-Lara, B., Raes, D., \& Fereres, E. (2009). AquaCrop- the FAO crop model to simulate yield response to water: III. Parameterization and testing for maize. Agronomy Journal, 101, 448-459. http://dx.doi.org/10.2134/agronj2008.0218s

Hussain, G., \& Al-Jaloud, A. A. (1995). Effect of irrigation and nitrogen on water use efficiency of wheat in Saudi Arabia. Agricultural Water Management, 27, 143-153. http://dx.doi.org/10.1016/0378-3774 (95)91233-W

Juskiw, P., \& Helm, J. (2003). Barley response to seeding date in central Alberta. Canadian Journal of Plant Science, 83, 275-281. http://dx.doi.org/ 10.4141/P02-049

Kalaji, H. M., Carpentier, R., Allakhverdiev, S. I., \& Bosa, K. (2012). Fluorescence parameters as early indicators of light stress in barley. Journal of Photochemistry and Photobiology B: Biology, 112, 1-6. http://dx.doi.org/10.1016/j.jphotobiol.2012.03.009

Kang, S., \& Zhang, J. (2004). Controlled alternate partial root-zone irrigation: its physiological consequences and impact on water use efficiency. Journal of Experimental Botany, 55, 2437-2446. http://dx.doi.org/ $10.1093 / \mathrm{jxb} / \mathrm{erh} 249$

Kirda, C., \& Kanber, R. (1999). Water, no longer a plentiful resource, should be used sparingly in irrigated agriculture. Crop Yield Response to Deficit Irrigation, 1-20.

McKenzie, R., Middleton, A., \& Bremer, E. (2005). Fertilization, seeding date, and seeding rate for malting barley yield and quality in southern Alberta. Canadian Journal of Plant Science, 85, 603-614. http://dx.doi.org/10.4141/P04-152

Mohammadi, P. P., Moieni, A., \& Komatsu, S. (2012). Comparative proteome analysis of drought-sensitive and drought-tolerant rapeseed roots and their hybrid F1 line under drought stress. Amino Acids, 43, 2137-2152. http://dx.doi.org/ 10.1007/s00726-012-1299-6

Nagaz, K., Toumi, I., Masmoudi, M. M., \& Mechilia, N. (2008). Soil salinity and barley production under full and deficit irrigation with saline water in Arid conditions of Southern Tunisia. Res. J. Agron, 2, 90-95.

Nass, H., Johnston, H., MacLeod, J., \& Sterling, J. (1975). Effects of seeding date, seed treatment and foliar sprays on yield and other agronomic characters of wheat, oats and barley. Canadian Journal of Plant Science, 55, 41-47. http://dx.doi.org/ 10.4141/cjps75-005

Noworolnik, K. (2012). Morphological characters, plant phenology and yield of spring barley (Hordeum sativum L.) depending on cultivar properties and sowing date. Acta Agrobotanica, 65, http://dx.doi.org/10.5586/aa.2012.071

Ozer, H. (2003). Sowing date and nitrogen rate effects on growth, yield and yield components of two summer rapeseed cultivars. European Journal of Agronomy, 19, 453-463. http://dx.doi.org/10.1016/S1161-0301 (02) 00136-3

Qi, J. C., Chen, J. X., Wang, J. M., Wu, F. B., Cao, L.P., \& Zhang, G. P. (2005). Protein and hordein fraction content in barley seeds as affected by sowing date and their relations to malting quality. Journal of Zhejiang University Science, B6, 1069. 
Raes, D., Steduto, P., Hsiao, T., \& Fereres, E. (2010). AquaCrop reference manual. AquaCrop Version, 3, 1. FAO Land and Water Division, Rome, Italy.

Rashid, A., \& UllahKhan, R. (2010). Response of Barley to sowing date and fertilizer application under rainfed condition. World Journal of Agricultural Sciences, 6, 480-484.

Razzaghi, F., \& Sepaskhah, A. R. (2012). Calibration and validation of four common ET0 estimation equations by lysimeter data in a semi-arid environment. Archives of Agronomy and Soil Science, 58, 303-319. http://dx.doi.org/10.1080/03650340.2010.518957

Sarker, M. A. R., Alam, K., \& Gow, J. (2012). Exploring the relationship between climate change and rice yield in Bangladesh: An analysis of time series data. Agricultural Systems, 112, 11-16. http://dx.doi.org/10.1016/j.agsy.2012.06.004

Shabani, A., Haghighi, A., Sepaskhah, A., Emam, Y., \& Honar, T. (2010). Effect of water stress on grain yield, yield components and quality of winter rapeseed (Brasica Napus L.). CV: Licord. Iranian Journal of Crop Sciences, 12, 409-421.

Shabani, A., Sepaskhah, A., \& Kamgar-Haghighi, A. (2013). Growth and physiologic response of rapeseed (Brassica napus L.) to deficit irrigation, water salinity and planting method. International Journal of Plant Production, 7, 569-596.

Supit, I., \& Wagner, W. (1999). Analysis of yield, sowing and flowering dates of barley of field survey results in Spain. Agricultural Systems, 59, 107-122. http://dx.doi.org/10.1016/S0308-521X (98) 00083-3

Tabarzad, A., \& Ghaemi, A. A. (2015). Deficit irrigation and sowing date as strategies to maximize water use efficiency and crop water productivity in semi-arid region. Biological Forum, 7, 30-42.

Zhang, H., \& Oweis, T. (1999). Water-yield relations and optimal irrigation scheduling of wheat in the Mediterranean region. Agricultural Water Management, 38, 195-211. http://dx.doi.org/10.1016/S0378-3774 (98) 00

\section{Copyrights}

Copyright for this article is retained by the author(s), with first publication rights granted to the journal.

This is an open-access article distributed under the terms and conditions of the Creative Commons Attribution license (http://creativecommons.org/licenses/by/4.0/). 